\title{
KECERNAAN LEMAK KASAR DAN BOBOT KARKAS AYAM BROILER AKIBAT PENAMBAHAN EKSTRAK BUAH MENGKUDU (Morinda citrifolia L.) DAN Lactobacillus acidophilus
}

\section{The Digestibility of Crude Fat and The Carcass Weight of Broiler Chickens Due To Feeding Noni Fruit Extract (Morinda Citrifolia L.) and Lactobacillus acidophilus}

\author{
Hari Setyoko1, Bambang Sukamto², Fajar Wahyono², dan Lilik Krismiyanto ${ }^{2}$ \\ ${ }_{1}^{1}$ Program Studi Peternakan, Fakultas Peternakan dan Pertanian, Universitas Diponegoro \\ 2Departemen Peternakan, Fakultas Peternakan dan Pertanian, Universitas Diponegoro \\ Email: harisetyoko@students.undip.ac.id
}

\begin{abstract}
ABSTRAK
Penelitian ini bertujuan untuk mengetahui pengaruh penambahan kombinasi Ekstrak Buah Mengkudu (EBM) dan Lactobacillus acidophilus (LA) terhadap kecernaan lemak kasar, persentase lemak abdominal, dan bobot karkas ayam broiler. Rancangan penelitian yang digunakan adalah Rancangan Acak Lengkap (RAL) pola faktorial 3x3 dengan 9 perlakuan dan 3 ulangan (setiap unit percobaan berisi 7 ekor ayam broiler). Perlakuan yang diterapkan pada penelitian yaitu A1B1 = EBM $0,04 \%+$ LA 0\%; A1B2 = EBM 0,04\% + LA 0,6\%; A1B3 = EBM 0,04\% + LA 1,2\%; A2B1 = EBM 0,08\% + LA 0\%; A2B2 = EBM 0,08\% + LA 0,6\%; A2B3 = EBM 0,08\% + LA 1,2\%; A3B1 = EBM 0,12\% + LA 0\%; A3B2 = EBM 0,12\% + LA 0,6\%; A3B3 = EBM 0,12\% + LA 1,2\%. Parameter yang diukur meliputi kecernaan lemak kasar, persentase lemak abdominal, dan bobot karkas ayam broiler. Hasil penelitian dianalisis ANOVA. Apabila terdapat perbedaan tingkat signifikansi maka dilakukan uji lanjut dengan Uji Jarak Berganda Duncan. Hasil menunjukkan bahwa penambahan kombinasi EBM dan LA berpengaruh nyata $(\mathrm{p}<0,05)$ terhadap kecernaan lemak kasar, persentase lemak abdominal, dan bobot karkas ayam broiler. Kesimpulan penelitian yaitu penambahan kombinasi ekstrak buah mengkudu pada taraf 0,12\% dan Lactobacillus acidophilus 1,2\% dapat meningkatkan kecernaan lemak kasar dan bobot karkas namun menurukan persentase lemak abdominal.

Kata kunci: Ekstrak Buah Mengkudu, Karkas Ayam Broiler, Kecernaan Lemak Kasar, Lactobacillus acidophilus, Lemak Abdominal
\end{abstract}

\begin{abstract}
This study aimed to determine the effect of adding a combination of Noni Fruit Extract (NFE) and Lactobacillus acidophilus (LA) on the digestibility of crude fat, the percentage of abdominal fat, and carcass weight of broiler chickens. The experimental design used completely randomized design $3 \times 3$ factorial design with 9 treatment levels and 3 replications (each 7 birds). The treatment levels applied were $A 1 B 1=N F E 0.04 \%+L A 0 \% ; A 1 B 2=N F E 0.04 \%+L A 0.6 \% ; A 1 B 3=N F E 0.04 \%+L A 1.2 \% ; A 2 B 1=$ NFE 0.08\% + LA 0\%; A2B2 = NFE 0.08\% + LA 0.6\%; A2B3 = NFE 0.08\% + LA 1.2\%; A3B1 = NFE 0.12\% + LA 0\%; A3B2 = NFE 0.12\% + LA 0.6\%; A3B3 = NFE 0.12\% + LA 1.2\%. The parameters included the digestibility of crude fat, the percentage of abdominal fat, and carcass weight. The results analyzed by ANOVA. When there were differences in the level of significance then tested further using the Duncan's Multiple Range Test. The results showed that the addition of NFE and LA combination presented a significant effect $(p<0.05)$ on the digestibility of crude fat, the percentage of abdominal fat, and the carcass weight of broiler chickens. The conclusion is the addition of combination of noni fruit extract $0.12 \%$ and Lactobacillus acidophilus $1.2 \%$ increase the digestibility of crude fat and carcass weight however reduce the percentage of abdominal fat.
\end{abstract}

Keywords: Noni Fruit Extract, Broiler Carcass, Crude Fat Digestibility, Lactobacillus Acidophilus, Abdominal Fat 


\section{PENDAHULUAN}

Ayam broiler merupakan jenis ayam ras pedaging yang paling banyak dikembangkan di Indonesia. Populasi ayam broiler tiap tahun mengalami peningkatan, populasi ayam broiler di Indonesia pada tahun 2017 sebanyak 1.848.731.364 ekor dan meningkat menjadi 1.891.434.612 ekor pada tahun 2018 (Direktorat Jenderal Peternakan dan Kesehatan Hewan, 2018). Peningkatan populasi ini didasari oleh kesadaran masyarakat akan pentingnya konsumsi protein hewani yang semakin meningkat. Hal ini ditunjukan dengan konsumsi daging ayam broiler pada tahun 2016 sebesar 5,110 kg yang meningkat pada tahun 2017 sebesar 5,680 kg (Direktorat Jenderal Peternakan, 2018). Permintaan masyarakat akan daging ayam broiler yang meningkat, perlu dilakukan upaya untuk meningkatkan produktivitas ayam broiler. Salah satu upaya yang dapat dilakukan yaitu dengan pengoptimalan sistem pencernaan sehingga produktivitas ayam broiler dapat meningkat secara optimal. Pengoptimalan sistem pencernaan dapat diupayakan melalui salah satu cara yaitu dengan menambahkan probiotik dalam ransum.

Probiotik merupakan zat aditif berupa mikroba hidup yang ditambahkan kedalam ransum dengan tujuan menjaga keseimbangan mikrobia dalam saluran pencernaan (Mikulski, et al., 2012). Lactobacillus acidophilus merupakan golongan bakteri yang masuk kedalam probiotik serta bakteri penghasil asam laktat (BAL), merupakan bakteri gram positif, berbentuk batang dengan ujung berbentuk bulat. Lactobacillus acidophilus berperan melindungi saluran pencernaan dari bakteri patogen sehingga saluran pencernaan dapat bekerja dengan baik dan mampu memproduksi asam laktat sebagai hasil dari proses fermentasi gula (Adriani, Tanuwiria, \& Mayasari, 2008). Saluran pencernaan yang sehat dapat meningkatkan penyerapan nutrien sehingga produktivitas ayam broiler dapat meningkat.

Produktivitas ayam broiler dapat meningkat juga ditunjang oleh sehatnya ayam broiler pada masa pemeliharaan. Perlu adanya upaya untuk menjaga kesehatan ayam broiler pada saat masa pemeliharaan. Antioksidan merupakan senyawa yang berperan dalam meningkatkan kesehatan tubuh dan mencegah terjadinya radikal bebas. Buah mengkudu (Morinda citrifolia L) memiliki kandungan antioksidan yang berperan baik dalam menjaga kesehatan tubuh. Kandungan antioksidan yang terdapat pada buah mengkudu diantaranya yaitu flavonoid dan senyawa fenolik (Rao \& Subramanian, 2009). Buah mengkudu memiliki kandungan flavonoid sebesar 5,69 $\pm 0,21 \mathrm{mg}$, senyawa fenolik sebesar 14,44 $\pm 0,82 \mathrm{mg}$ dan aktivitas antioksidan sedang sebesar (IC50 101-250 $\mu \mathrm{g} / \mathrm{mL}$ ) (Anwar \& Triyasmono, 2016). Buah mengkudu memiliki khasiat sebagai obat kemoterapi (Karamcheti et al., 2014), antimikroba (Sashidharan \& Palaniswamy, 2010), antidepresan (Deng \& West, 2011), dan antioksidan (Saminathan et al., 2014).

Pemberian kombinasi ekstrak buah mengkudu dan Lactobacillus acidophilus pada ayam broiler bertujuan untuk meningkatkan kesehatan dan fungsi saluran pencernaan. Pakan dengan penambahan kombinasi ekstrak buah mengkudu dan Lactobacillus acidophilus dapat berpengaruh terhadap laju kecernaan. Laju kecernaan termasuk dalam salah satu indikator untuk mengetahui tingkat kualitas pakan yang diberikan, sehingga penambahan ekstrak buah mengkudu dan Lactobacillus acidophilus termasuk dalam kombinasi pakan untuk ayam broiler. Pemberian kombinasi tersebut dapat mempengaruhi densitas dan panjang villi pada usus, luas permukaan usus untuk menyerap nutrien lebih banyak sehingga meningkatkan jumlah konsumsi ransum (Kompiang, 2009). Konsumsi yang meningkat berarti meningkat pula konsumsi lemak, hal ini berarti lemak yang terabsorbsi lebih banyak sehingga kecernaan lemak dapat semakin meningkat (Pramudia et al., 2013). Tujuan dari penelitian ini adalah untuk mengkaji pengaruh penambahan kombinasi ekstrak buah mengkudu dan Lactobacillus acidophilus terhadap kecernaan lemak kasar, persentase lemak abdominal, dan bobot karkas ayam broiler. 


\section{METODE}

\section{Waktu dan Tempat}

Penelitian ini dilaksanakan pada bulan November 2019 - Januari 2020 di kandang digesti unggas dan non-ruminansia, Fakultas Peternakan dan Pertanian, Universitas Diponegoro, Semarang. Analisis Proksimat dilakukan di laboratorium Ilmu Nutrisi dan Pakan, Fakultas Peternakan dan Pertanian, Universitas Diponegoro, Semarang.

\section{Ternak, Ransum, dan Peralatan}

Ternak yang digunakan dalam penelitian yaitu ayam broiler strain CP707 sebanyak 189 ekor unsex, umur 7 hari dengan bobot badan rata-rata $152 \mathrm{~g}$. Bahan yang digunakan yaitu ekstrak buah mengkudu dan Lactobacillus acidophilus serta ransum pakan yang tersusun dari jagung giling, bekatul, bungkil kedelai, tepung ikan, premix, CaCO3, metionin, dan lisin. Penyusunan ransum penelitian menggunakan metode trial and error dengan memperhatikan kebutuhan ayam broiler fase finisher dan kandungan nutrisi pakan tertera pada Tabel 1. Alat yang digunakan yaitu pisau, grinder, botol reagen, corong plastik, evaporator, tabung reaksi, suntikan, timbangan digital, soxhlet, nampan, termohigrometer, kandang brooder, kandang baterai, wadah pakan dan minum, kardus, trashbag serta peralatan laboratorium.

Tabel 1. Kandungan nutrien pakan

\begin{tabular}{|c|c|}
\hline Bahan Pakan & Komposisi (\%) \\
\hline Jagung giling & 52,00 \\
\hline Bekatul & 9,15 \\
\hline Bungkil kedelai & 28,00 \\
\hline Tepung Ikan & 10,00 \\
\hline $\mathrm{CaCO} 3$ & 0,25 \\
\hline Premix & 0,25 \\
\hline Metionin & 0,10 \\
\hline Lisin & 0,25 \\
\hline Total & 100 \\
\hline \multicolumn{2}{|l|}{ Kandungan Nutrien* (\%) } \\
\hline Protein Kasar & 21,45 \\
\hline Lemak Kasar & 4,27 \\
\hline Serat Kasar & 6,00 \\
\hline $\mathrm{Ca}$ & 1,19 \\
\hline $\mathrm{P}$ & 0,87 \\
\hline Metionin & 0,38 \\
\hline Lisin & 1,38 \\
\hline
\end{tabular}

Keterangan: *Berdasarkan analisis proksimat bahan pakan di Laboratorium Ilmu Nutrisi dan Pakan, Fakultas Peternakan dan Pertanian, Universitas Diponegoro (2020)

\section{Pembuatan Ekstrak Buah Mengkudu}

Pembuatan ekstrak buah mengkudu diawali dengan mencari buah mengkudu yang sudah setengah matang berwarna putih kekuningan. Selanjutnya buah mengkudu dipotong tipis-tipis agar mempercepat proses pengeringan, kemudian setelah itu dilakukan pengeringan di bawah sinar matahari sampai berbentuk kering kecoklatan. Selanjutnya, mengkudu yang sudah kering dihaluskan menggunakan grinder dengan tujuan merubah bentuk mengkudu menjadi lebih halus atau 
berbentuk tepung. Langkah selanjutnya yaitu maserasi, tepung buah mengkudu sebanyak 250 gr ditambahkan dengan 1 liter alcohol 70\% kemudian dimasukan ke dalam botol kemudian dilakukan pengadukansetiap 12 jam sekali selama 2 hari. Hasil dari proses maserasi berupa larutan, kemudian larutan tersebut dievaporasi menggunakan evaporator selama 1 jam dengan suhu $50{ }^{\circ} \mathrm{C}$. Setelah dievaporasi ekstrak buah mengkudu disimpan di dalam refrigerator dan siap digunakan untuk perlakuan.

\section{Persiapan, Pemeliharaan dan Pengamatan}

Persiapan kandang dilakukan meliputi pembersihan kandang, pengapuran lantai, dinding dan kandang, fumigasi serta menyiapkan peralatan kandang. Lama pemeliharaan ayam broiler pada penelitian ini yaitu selama 35 hari. Proses chick in dilaksanakan pada 29 November 2019 kemudian DOC dipilih secara acak untuk ditimbang sebagai bobot awal. Pemeliharaan mulai pada hari ke 1 sampai hari ke 7 diberikan pakan berupa ransum komersial. Setelah 7 hari, pemeliharaan berikutnya merupakan masa adaptasi, ayam broiler diberikan pakan berupa campuran antara ransum komersial dan ransum perlakuan dengan perbandingan 80:20, 70:30, 60:40, 50:50, 40:60, 30:70, dan 20:80. Ransum perlakuan diberikan utuh mulai umur 15 hari sampai 35 hari. Parameter yang diamati yaitu kecernaan lemak, lemak abdominal, serta bobot karkas ayam broiler. Parameter bobot karkas dan lemak abdominal diukur bersamaan ketika carcassing pada hari ke 36 dengan mengambil satu ekor ayam broiler secara acak pada tiap unit percobaan. Total koleksi ekskreta dilakukan pada hari ke 38 sampai hari ke 45 dengan ransum perlakuan yang diberi pewarna atau indikator berupa $\mathrm{Fe}_{2} \mathrm{O}_{3}$ sebanyak $0,5 \%$ dari jumlah pemberian ransum harian. Pemberian ransum perlakuan indikator dilakukan berselang dengan ransum perlakuan tanpa indikator selama 6 hari yaitu pada hari ke 38, 40, 42 dan 44. Hal tersebut dilakukan karena bersamaan dengan pengamatan laju digesta ayam broiler. Selanjutnya, ekskreta ditampung setiap hari nya dan dipisahkan dari benda selain ekskreta kemudian dikeringkan di bawah sinar matahari. Ekskreta yang sudah kering lalu di blender dan disaring menjadi tepung ekskreta yang digunakan dalam pengukuran parameter kecernaan lemak.

\section{Rancangan Percobaan dan Perlakuan}

Penelitian disusun dalam rancangan acak lengkap (RAL) pola faktorial 3x3 dengan 9 perlakuan dan 3 ulangan sehingga terdapat 27 unit percobaan yang dimana setiap unit terdiri dari 7 ekor ayam. Perlakuan yang diterapkan sebagai berikut:

A1B1 : Ekstrak Buah Mengkudu 0,04\% + Lactobacillus acidophilus 0\%

A1B2 : Ekstrak Buah Mengkudu 0,04\% + Lactobacillus acidophilus 0,6\%

A1B3 : Ekstrak Buah Mengkudu 0,04\% + Lactobacillus acidophilus 1,2\%

A2B1 : Ekstrak Buah Mengkudu 0,08\% + Lactobacillus acidophilus 0\%

A2B2 : Ekstrak Buah Mengkudu 0,08\% + Lactobacillus acidophilus 0,6\%

A2B3 : Ekstrak Buah Mengkudu 0,08\% + Lactobacillus acidophilus 1,2\%

A3B1 : Ekstrak Buah Mengkudu 0,12\% + Lactobacillus acidophilus 0\%

A3B2 : Ekstrak Buah Mengkudu 0,12\% + Lactobacillus acidophilus 0,6\%

A3B3 : Ekstrak Buah Mengkudu 0,12\% + Lactobacillus acidophilus 1,2\%

\section{Parameter dan Metode Pengukuran}

Parameter yang diukur yaitu kecernaan lemak, lemak abdominal, serta bobot karkas ayam broiler. Perhitungan bobot karkas didapat dengan menimbang karkas ayam broiler. Perhitungan kecernaan lemak diawali dengan menganalisis kadar lemak ransum dan ekskreta. Selanjutnya, dikalikan konsumsi ransum dan dikurangi lemak ekskreta dibagi dengan konsumsi lemak. Ekskreta yang sudah kering dilanjutkan uji lemak dengan soxhlet. Hasil proses soxhlet, kemudian diangin- 
anginkan terlebih dahulu. Kecernaan lemak dihitung dengan rumus menurut Moningkey et al. (2019) sebagai berikut:

$$
\text { Kecernaan lemak : } \frac{\text { konsumsi lemak ransum - kadar lemak eksreta }}{\text { konsumsi lemak }} \times 100 \%
$$

Perhitungan persentase bobot relatif lemak abdominal didapat dengan menimbang lemak abdominal yang terdapat pada rongga perut ayam broiler. Bobot relatif lemak abdominal dihitung menggunakan rumus sebagai berikut :

$$
\text { Persentase Bobot relatif lemak abdominal: } \frac{\text { lemak abdomen }}{\text { bobot hidup }} \times 100 \%
$$

\section{Analisis Statistik}

Data diuji menggunakan analisis varian berdasarkan rancangan acak lengkap dengan membandingkan nilai F hitung dengan F tabel pada taraf signifikasi 5\%. Apabila pengaruh perlakuan nyata dilanjutkan uji Duncan untuk mengetahui perbedaan nilai tengah antar perlakuan. Model linier untuk seluruh pengamatan adalah sebagai berikut:

$$
Y_{i j k}=\mu+\alpha_{i}+\beta_{j}+(\alpha \beta)_{i j}+\varepsilon_{i j k}
$$

\section{Keterangan :}

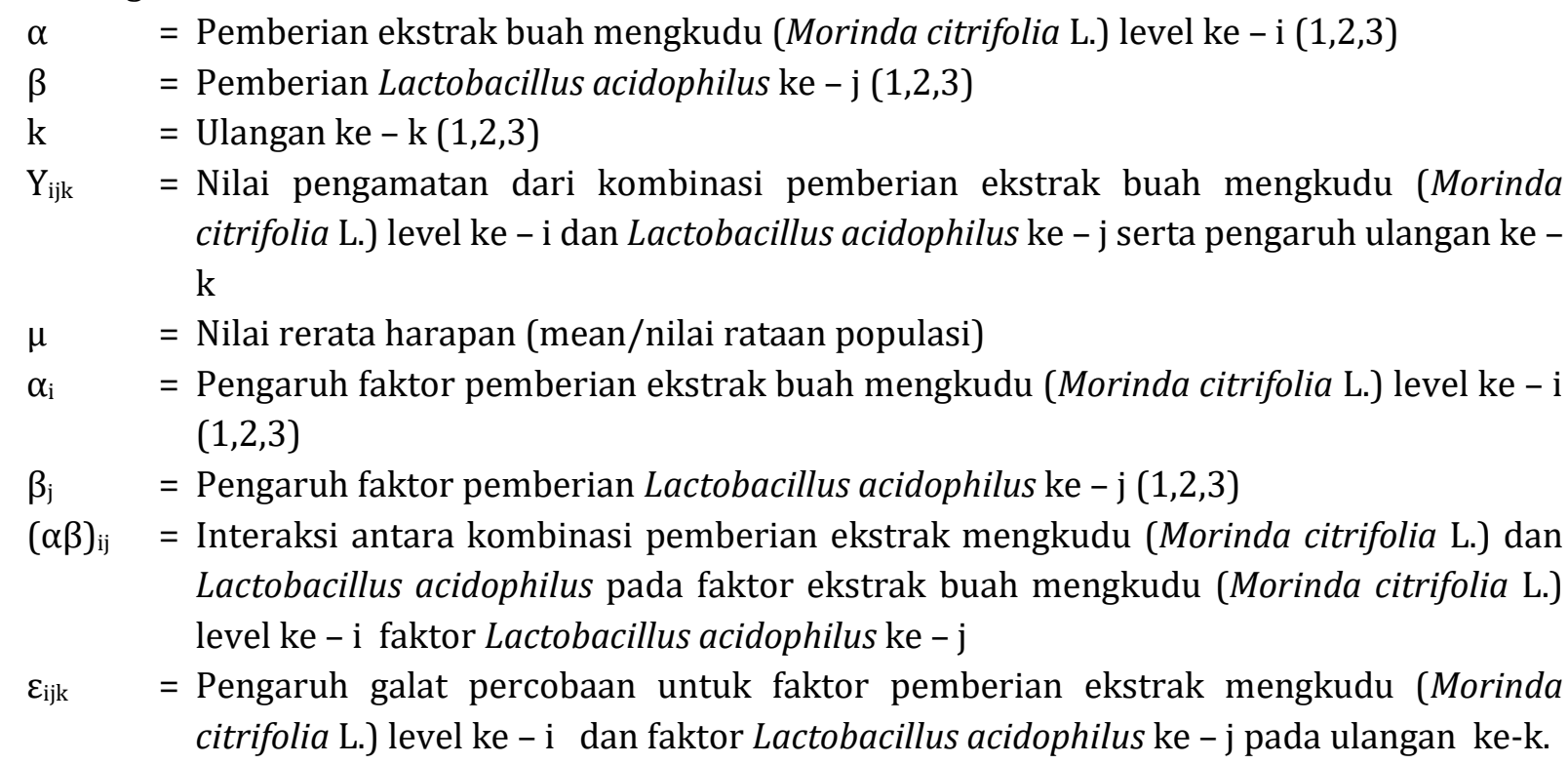

\section{Hipotesis}

H0: $\alpha_{\mathrm{i}}=0$; maka, tidak terdapat pengaruh dari pemberian ekstrak mengkudu (Morinda citrifolia L.) terhadap kecernaan lemak kasar, bobot relatif lemak abdominal dan bobot karkas ayam broiler.

$\beta_{\mathrm{j}} \quad=0$; maka, tidak terdapat pengaruh dari pemberian Lactobacillus achidophillus terhadap kecernaan lemak kasar, bobot relatif lemak abdominal dan bobot karkas ayam broiler.

$(\alpha \beta)_{\mathrm{ij}}=0$; maka, tidak terdapat interaksi dari kombinasi pemberian (Morinda citrifolia L.) dan Lactobacillus achidophillus terhadap kecernaan lemak kasar, bobot relatif lemak abdominal dan bobot karkas ayam broiler. 
H1: $\quad \alpha_{\mathrm{i}} \quad \neq 0$; maka, terdapat pengaruh dari pemberian ekstrak mengkudu (Morinda citrifolia L.) terhadap kecernaan lemak kasar, bobot relatif lemak abdominal dan bobot karkas ayam broiler.

$\beta_{\mathrm{j}} \neq 0$; maka, terdapat pengaruh dari pemberian Lactobacillus achidophillus terhadap kecernaan lemak kasar, bobot relatif lemak abdominal dan bobot karkas ayam broiler.

$(\alpha \beta)_{\mathrm{ij}} \neq 0$; maka, terdapat interaksi dari kombinasi pemberian (Morinda citrifolia L.) dan Lactobacillus achidophillus terhadap kecernaan lemak kasar, bobot relatif lemak abdominal dan bobot karkas ayam broiler.

\section{HASIL DAN PEMBAHASAN}

Berdasarkan penelitian yang telah dilaksanakan didapatkan hasil data berupa nilai kecernaaan lemak kasar, persentase bobot relatif lemak abdominal serta bobot karkas ayam broiler akibat penambahan kombinasi ekstrak buah mengkudu (Morinda citrifolia L) dan Lactobacillus acidophilus yang disajikan pada Tabel 2.

Tabel 2. Kecernaan lemak kasar, persentase bobot relatif lemak abdominal, dan bobot karkas ayam broiler akibat penambahan kombinasi ekstrak buah mengkudu (Morinda Citrifolia L) Dan Lactobacillus Acidophilus

\begin{tabular}{cccc}
\hline \multirow{2}{*}{ Perlakuan } & \multicolumn{3}{c}{ Parameter } \\
\cline { 2 - 4 } & $\begin{array}{c}\text { Kecernaan Lemak } \\
\text { Kasar (\%) }\end{array}$ & Bobot Karkas (g/ekor) & $\begin{array}{c}\text { Persentase Bobot Relatif } \\
\text { Lemak Abdominal (\%) }\end{array}$ \\
\hline A1B1 & $85,73^{\mathrm{a}}$ & $795,00^{\mathrm{e}}$ & $0,89^{\mathrm{a}}$ \\
A1B2 & $83,29^{\mathrm{b}}$ & $937,67^{\mathrm{bcd}}$ & $0,80^{\mathrm{a}}$ \\
A1B3 & $82,53^{\mathrm{bc}}$ & $969,67^{\mathrm{bc}}$ & $0,43^{\mathrm{b}}$ \\
A2B1 & $84,62^{\mathrm{ab}}$ & $879,33^{\mathrm{d}}$ & $0,91^{\mathrm{a}}$ \\
A2B2 & $84,29^{\mathrm{ab}}$ & $918,67^{\mathrm{cd}}$ & $0,44^{\mathrm{b}}$ \\
A2B3 & $80,82^{\mathrm{c}}$ & $915,67^{\mathrm{cd}}$ & $0,33^{\mathrm{b}}$ \\
A3B1 & $86,02^{\mathrm{a}}$ & $901,33^{\mathrm{d}}$ & $0,56^{\mathrm{b}}$ \\
A3B2 & $81,03^{\mathrm{c}}$ & $984,33^{\mathrm{ab}}$ & $0,43^{\mathrm{b}}$ \\
A3B3 & $78,44^{\mathrm{d}}$ & $1029,33^{\mathrm{a}}$ & $0,34^{\mathrm{b}}$ \\
\hline
\end{tabular}

Superskrip yang berbeda pada kolom yang sama menunjukkan perbedaan yang nyata $(\mathrm{P}<0,05)$

\section{Kecernaan Lemak Kasar}

Hasil analisis ragam menunjukkan bahwa penambahan kombinasi ekstrak buah mengkudu dan Lactobacillus acidophilus berpengaruh nyata $(\mathrm{P}<0,05)$ terhadap kadar kecernaan lemak kasar. Kecernaan lemak kasar hasil penelitian berkisar antara 78,44\% - 86,02\%. Hasil uji Duncan menunjukkan bahwa perlakuan A3B1 pada Tabel 2 menghasilkan kecernaan lemak kasar paling tinggi. Menurut Irawan et al. (2011) tingkat kecernaan yang tinggi menunjukkan zat-zat pakan yang diserap oleh tubuh semakin tinggi pula. Kecernaan lemak kasar yang tinggi tersebut diduga disebabkan oleh aktivitas antioksidan ekstrak buah mengkudu yang mampu merespon pertumbuhan serta memperbaiki mikroflora organ pencernaan. Menurut Aji et al. (2017) keberadaan mikroflora di dalam usus halus akan mempengaruhi kesehatan dan perkembangan usus halus serta dapat meningkatkan absorbsi nutrien. Selain itu, senyawa proxeronin dan xeronin yang ada di ekstrak buah mengkudu dapat membantu usus halus dalam proses penyerapan zat makanan.

Menurut Djauhariya (2006), proxeronin mempercepat penyerapan zat makanan ke dalam sistem pencernaan. Enzim proxeroninase membantu merubah proxeronine menjadi xeronine di 
dalam usus halus. Heinicke (2001) menyatakan bahwa xeronin mampu memodifikasi struktur molekul protein serta memiliki berbagai aktivitas biologis. Menurut Djauhariya (2006), xeronin membantu proses penyerapan menjadi lebih cepat karena mampu memperluas lubang usus halus sehingga zat makanan dapat lebih banyak terserap dan tidak lama tertinggal di dalam usus halus.

\section{Bobot Karkas}

Hasil analisis ragam menunjukkan bahwa penambahan kombinasi ekstrak buah mengkudu dan Lactobacillus acidophilus berpengaruh nyata $(\mathrm{P}<0,05)$ terhadap bobot karkas ayam broiler. Bobot karkas ayam broiler hasil penelitian berkisar antara 795,00 - 1029,33 g/ekor. Hasil uji Duncan menunjukkan bahwa perlakuan A3B3 pada Tabel 2 menghasilkan bobot karkas ayam broiler paling tinggi. Hal tersebut menunjukkan bahwa perlakuan dengan kombinasi level tertinggi mampu menaikkan bobot karkas. Hal itu disebabkan oleh populasi BAL yang meningkat dalam saluran pencernaan sehingga penyerapan nutrien maksimal dalam usus. Menurut Rochman et al. (2019) populasi BAL di usus akan menfermentasi karbohidrat molekul rendah dalam ransum sehingga menghasilkan short chain fatty acid dan menyebabkan menurunnya pH usus. Kondisi asam dalam usus menekan pertumbuhan bakteri pathogen sehingga proses pencernaan dan penyerapan nutrient dalam usus akan maksimal. Sa'diyah et al. (2020) menyatakan bahwa penambahan kombinasi ekstrak buah mengkudu dan Lactobacillus acidophilus dalam pakan ayam broiler mampu menaikkan populasi BAL mencapai $8,42 \times 10^{10} \mathrm{cfu} / \mathrm{g}$. Faktor lain yang mempengaruhi adalah kecernaan protein ransum yang tinggi sehingga pertumbuhan daging juga lebih maksimal. Rochman et al. (2019) menyatakan bahwa penambahan kombinasi ekstrak buah mengkudu dan Lactobacillus acidophilus dalam pakan ayam broiler mampu meningkatkan kecernaan protein mencapai 84,44\%. Penyerapan nutrien dan protein pakan yang optimal akan berdampak pada produktivitas ternak yang tinggi pula terutama pada bobot karkasnya yang tinggi serta rendah lemak.

\section{Persentase Bobot Relatif Lemak Abdominal}

Hasil analisis ragam pada parameter persentase bobot relatif lemak abdominal menunjukkan bahwa penambahan kombinasi ekstrak buah mengkudu dan Lactobacillus acidophilus berpengaruh nyata $(\mathrm{P}<0,05)$ terhadap persentase bobot relatif lemak abdominal. Persentase bobot relatif lemak abdominal hasil penelitian berkisar antara 0,33\% - 0,91\% untuk masing-masing perlakuan. Hasil uji Duncan menunjukkan bahwa perlakuan A2B3 yang ditunjukkan pada Tabel 2 menghasilkan persentase bobot relatif lemak abdominal paling rendah. Hal itu disebabkan oleh senyawa alkaloid triterpenoid yang terkandung pada ekstrak buah mengkudu. Menurut Wijayakusuma et al. (1992), buah mengkudu mengandung alkaloid triterpenoid yang berfungsi mengatasi darah tinggi dan kegemukan. Kegemukan dalam hal ini dapat diartikan juga sebagai salah satu bentuk penumpukan lemak pada ayam broiler. Di dalam ekstrak buah mengkudu juga mengandung senyawa steroid yang disebut a-sitosterol. Senyawa steroid yang terkandung dalam buah mengkudu memberikan pengaruh yang baik khususnya untuk penurunan kadar kolesterol. Fenita et al. (2011) menyatakan bahwa senyawa steroid yang disebut a-sitosterol ini bekerja dengan cara memblok penyerapan kolesterol sehingga dapat menurunkan kadar kolesterol dalam darah.

Penurunan kadar kolesterol tersebut diikuti juga dengan menurunnya kadar lemak dalam daging. Selain itu, faktor lain yang menurunkan persentase bobot relatif lemak abdominal dapat disebabkan oleh aktivitas probiotik Lactobacillus acidophilus dalam perlakuan. Probiotik mampu menurunkan aktivitas asetil KoA karboksilase yang berperan dalam laju sintesis asam lemak. Menurut Krismaputri et al. (2016), Asetil KoA karboksilase merangsang sel adiposa mengoksidasi dan menghidrolisis lemak. Enzim Asetil KoA karboksilase membantu biosintesis malonyl KoA dari 
asetil KoA sehingga rantai asam lemak dapat diperpanjang dan menyebabkan terjadinya hidrolisis lemak sehingga penyimpanan lemak abdominal menjadi berkurang.

\section{KESIMPULAN}

Berdasarkan hasil penelitian dapat disimpulkan bahwa penambahan kombinasi ekstrak buah mengkudu dan Lactobacillus acidophilus mampu meningkatkan kecernaan lemak kasar dan bobot karkas ayam broiler serta menurunkan persentase bobot relatif lemak abdominal. Penambahan yang paling efektif yaitu pada level kombinasi ekstrak buah mengkudu 0,12\% dan Lactobacillus acidophilus $1,2 \%$.

\section{UCAPAN TERIMA KASIH}

Kami ucapkan terima kasih kepada Laboratorium Ilmu Nutrisi dan Pakan, Fakultas Peternakan dan Pertanian, Universitas Diponegoro, Semarang untuk tempat terlaksananya penelitian ini. Kami haturkan pula terima kasih kepada Prof. Dr. Ir. Bambang Sukamto, S.U., drh. Fajar Wahyono, M.P. dan Lilik Krismiyanto, S.Pt., M.Si. serta segenap tim noni yaitu Malik, Ridwan, Ade, Ani dan Safira.

\section{DAFTAR PUSTAKA}

Adriani, L., Indrayati, N., Tanuwiria, U. H., \& Mayasari, N. (2008). Aktivitas Lactobacillus acidophilus dan Bifidobacterium terhadap kualitas yoghurt dan penghambatannya pada Helicobacter pylori. Bionatura, 10(2), 218406.

Aji, H. I., Yudiarti, T., \& Isroli. (2017). Pengaruh lama pemberian spirulina platensis dalam pakan terhadap bobot organ limfoid dan usus halus ayam broiler. Seminar Nasional Pengembangan Peternakan Berkelanjutan 9 (pp. 298 - 302). Sumedang: Fakultas Peternakan Universitas Padjadjaran.

Anwar, K., \& Triyasmono, L. (2019). Kandungan total fenolik, total flavonoid, dan aktivitas antioksidan ekstrak etanol buah mengkudu (Morinda citrifolia L.). Jurnal Pharmascience, 3(1), 83-92.

Deng, S., \& West, B. (2011). Antidepressant effects of Noni fruit and its active principals. Asian Journal of Medical Sciences, 3(2), 79-83.

Direktorat Jenderal Peternakan. (2019). Statistik Peternakan dan Kesehatan Hewan 2019. Indonesia: Kementrian Pertanian.

Djauhariya, E., Rahardjo, M., \& Ma'mun. (2006). Karakterisasi morfologi dan mutu buah mengkudu. Buletin Plasma Nutfah, 12(1), 1-7.

Fenita, Y., Warnoto, W., \& Nopis, A. (2011). Pengaruh pemberian air buah mengkudu (Morinda citrifolia L) terhadap kualitas karkas ayam broiler. Jurnal Sain Peternakan Indonesia, 6(2), 143150.

Heinicke, R. M. (2001). The Xeronine-system: a new cellular mechanism that explains the health promoting action of Noni and Bromelain. Orem, Utah: Direct Source Publishing.

Irawan, I., Sunarti, D., \& Mahfudz, L. D. (2011). Pengaruh pemberian pakan bebas pilih terhadap kecernaan protein burung puyuh. Animal Agriculture Journal, 1(2), 238 - 245.

Karamcheti, S. A., Satyavati, D., Subramanian, N. S., Pradeep, H. A., \& Pradeep, C. (2014). Chemoprotective effect of ethanolic extract of Morinda citrifolia against Cisplatin induced nephrotoxicity. The Pharma Innovation, 3(1), 84-91.

Kompiang, I. P. (2009). Pemanfaatan mikroorganisme sebagai probiotik untuk meningkatkan produksi ternak unggas di Indonesia. Pengembangan Inovasi Pertanian., 2(3), 177-191.

Krismaputri, M. E., Suthama, N., \& Pramono, Y. B. (2016). Pemberian prebiotik soybean oligosakarida dari ekstrak bungkil dan kulit kedelai terhadap perlemakan dan bobot daging pada ayam broiler. Jurnal pengembangan dan penyuluhan pertanian, 13(24), 99 - 105. 
Mikulski, D. 1., Jankowski, J., Naczmanski, J., Mikulska, M., \& Demey, V. (2012). Effects of dietary probiotic (Pediococcus acidilactici) supplementation on performance, nutrient digestibility, egg traits, egg yolk cholesterol, and fatty acid profile in laying hens. Poultry science, 91(10), 2691-2700.

Moningkey A F, Wolayan F R, Rahasia C A, \& Regar M N. (2019). Kecernaan bahan organik, serat kasar dan lemak kasar pakan ayam pedaging yang diberi tepung limbah labu kuning (Cucurbita moschata). Zootech, 39(2), 257-265.

Pramudia, A., Mangisah, I., \& Sukamto, B. (2013). Kecernaan lemak kasar dan energi metabolis pada itik magelang jantan yang diberi ransum dengan level protein dan probiotik berbeda. J Animal Agriculture, 2(4), 148 - 160.

Rao, U. S., \& Subramanian, S. (2009). Biochemical evaluation of antihyperglycemic and antioxidative effects of Morinda citrifolia fruit extract studied in streptozotocin-induced diabetic rats. Medicinal Chemistry Research, 18(6), 433-446.

Rochman, F., Yuanita, I., Wahyuni, H. I., \& Suthama, N. (2019). Pengaruh ekstrak umbi bawang dayak (Eleutherine palmifolia) yang dikombinasikan dengan probiotik (Lactobacillus acidophilus) terhadap perlemakan pada ayam broiler. Seminar Nasional Pengelolaan Sumber Daya Alam Berkesinambungan Di Kawasan Gunung Berapi. Magelang: Universitas Tidar.

Sa'diyah S N, Sukamto B, Wahyono F, \& Krismiyanto L. (2020). Penambahan kombinasi ekstrak buah noni (Morinda citrifolia l.) dan Lactobacillus acidophilus dalam pakan terhadap profil lemak darah ayam pedaging. Jurnal Nutrisi Ternak Tropis, 3(2), 81-89.

Saminathan, Rb, R., Dhama, K., Jangir, B. L., S, S., Gj, R., . . Gopalakrishnan, A. (2014). Effect of Morinda citrifolia (Noni) fruit juice on antioxidant, hematological and biochemical parameters in $\mathrm{n}$ methyl-n-nitrosourea (NMU) induced mammary carcinogenesis in sprague-dawley rats. International Journal of Pharmacology, 78(3), 89-109.

Sashidharan, S., \& Palaniswamy, M. (2010). Antimicrobial activity of a rarely known species, Morinda citrifolia L. Ethnobotanical Leaflets, 14, 306-317.

Wijayakusuma, H. M., Dalimartha, S., \& Wirian, A. S. (1992). Tanaman Berkhasiat Obat di Indonesia. Jakarta: Pustaka Kartini. 